\title{
Epitrix papa sp. n. (Coleoptera: Chrysomelidae: Galerucinae: Alticini), previously misidentified as Epitrix similaris, is a threat to potato production in Europe
}

\author{
MARINA J. ORLOVA-BIENKOWSKAJA \\ A.N. Severtsov Institute of Ecology and Evolution, Russian Academy of Sciences, 33 Leninskiy Prospect, 119071 Moscow, Russia; \\ e-mail: marinaorlben@yandex.ru
}

Key words. Coleoptera, Chrysomelidae, Epitrix, flea beetle, Europe, introduced pest, potato, Solanum tuberosum, tubers

\begin{abstract}
A nonnative pest of potato recently established and causing significant economic damage in Portugal and Spain was initially identified as Epitrix similaris Gentner and included on lists of quarantine pests. The identity of this pest was doubted by some experts, since E. similaris is a rare species previously recorded only from California and does not damage potato in its native range. Our comparison of 20 specimens of this pest from Portugal with paratypes of E. similaris has revealed that it is not E. similaris. The name "Epitrix similaris" should be removed from lists of quarantine pests. The damage to potato tubers caused by the larvae of this pest is similar to that of E. tuberis Gentner, but examination of paratypes of E. tuberis has revealed that the pest is not $E$. tuberis. This pest differs from all species of Epitrix recorded in the Holarctic and from all known Epitrix pests of potato in the world. Herewith it is described as a new species Epitrix papa sp. n., whose native range is unknown.
\end{abstract}

\section{INTRODUCTION}

The representatives of the genus Epitrix Foudras (Coleoptera: Chrysomelidae: Galerucinae: Alticini) are tiny pubescent flea beetles that feed mainly on Solanaceae. Some species are serious pests of potato, egg-plant, tobacco and other cultivated plants. The genus is distributed worldwide and includes about 180 species (Döberl, 2000). Several pest species have been inadvertently introduced into and become established on other continents and oceanic islands far from their native ranges (Beenen \& Roques, 2010; Döberl, 2010). The identification of Epitrix species is difficult, since the taxonomy is poorly understood. In particular, North American species need to be revised as many species native to North America are still undescribed (Riley et al., 2002; Deczynski, 2014).

A new kind of potato tuber damage was detected in the Northern part of Portugal in 2004 (Boavida, 2009). In 2008 entire consignments of potatoes sent from Portugal to France, Spain and other countries were rejected because the tubers were damaged (Cuthbertson, 2015). This damage was caused by larvae of flea beetles of the genus Epitrix. The pest was identified as E. similaris Gentner, a rare North American species previously recorded only from California (Boavida \& Germain, 2009; Doguet, 2009; EPPO, 2011). At the same time another nonnative pest, $E$. cucumeris (Harris), native to North America was found in the northern part of Portugal. Experiments and observations have shown that larvae of the species identified as $E$. similaris damage tubers leaving superficial tracks ("worm tracks") and shallow holes. This species was the main cause of the damage to the potato crop in Portugal in 2008 (Boavida et al., 2013).
In 2010 E. similaris was included on the list A2 of quarantine pests of the European and Mediterranean Plant Protection Organization as a nonnative pest and a threat to potato production in Europe (EPPO, 2015). But the identity of the pest was doubted by some experts for zoogeographical and ecological reasons (Eyre \& Giltrap, 2012). First, E. similaris is not regarded as a pest in North America. Second, E. similaris is a rare species (Deczynski, 2014), so the probability of it spreading to another continent is low. Third, E. similaris has a very restricted distribution in America: it is only recorded in California (Riley et al., 2003) and it is believed that the origin of Epitrix in Portugal is bulk imports of seed potatoes from the Canadian provinces of Prince Edward Island and New Brunswick (Eyre \& Giltrap, 2012). The distance between California and this part of Canada is about $4000 \mathrm{~km}$. Epitrix similaris is not recorded in Canada (Riley et al., 2003; EPPO, 2015). In particular, it is not listed in the new list of Chrysomelidae of New Brunswick (Webster et al., 2012). The genetic study by Germain et al. (2013) proves that this species is not E. cucumeris, E. tuberis, E. hirtipennis (Melsheimer), E. subcrinita (LeConte) or E. fasciata Blatchley. But this study does not prove that it is E. similaris, since it was not compared with material of E. similaris from North America.

Currently Dr. A. Bieńkowski and I are preparing a key for the identification of all Epitrix species known from the Holarctic Region. So we decided to check the identification of the pest established in Portugal.

\section{MATERIAL}

316 specimens of 20 Epitrix species were obtained from the National Museum of Natural History (USA), Instituto Nacional 
TABLE 1. Examined material, photographs and figures.

\begin{tabular}{|c|c|c|c|c|c|c|}
\hline \multirow[b]{2}{*}{ Species } & \multicolumn{3}{|c|}{ Examined specimens } & \multicolumn{3}{|c|}{ Examined photographs and figures } \\
\hline & $\begin{array}{c}\text { Total } \\
\text { number }\end{array}$ & $\begin{array}{l}\text { Males with dis- } \\
\text { sected aedeagus }\end{array}$ & $\begin{array}{l}\text { Females with dis- } \\
\text { sected spermatheca }\end{array}$ & $\begin{array}{c}\text { General } \\
\text { view }\end{array}$ & Aedeagus & Spermatheca \\
\hline abeillei (Bauduer) & 31 & 13 & 17 & [4] & {$[5],[3],[8]$} & {$[5]$} \\
\hline allardii (Wollaston) & 1 & 1 & - & - & [5] & [5] \\
\hline atropae Foudras & 23 & 4 & 5 & [3] & {$[5],[8]$} & {$[5]$} \\
\hline brevis Schwarz & 3 & 2 & 1 & {$[4]$} & - & {$[4]$} \\
\hline caucasica (Heikertinger) & 9 & 2 & 4 & [3] & {$[5],[3],[8]$} & {$[5]$} \\
\hline cucumeris (Harris) & 11 & 3 & 5 & {$[4],[6]$} & {$[4],[5],[6]$} & {$[4],[5],[6]$} \\
\hline dieckmanni (Mohr) & 1 & 1 & - & [2] & [5] & [5] \\
\hline ermischi (Mohr) & 39 & 5 & 6 & - & {$[5]$} & {$[5]$} \\
\hline fasciata Blatchley & - & - & - & [4] & [5] & {$[5]$} \\
\hline flavotestacea Horn & - & - & - & {$[4]$} & - & {$[4]$} \\
\hline fuscata (Duval) & - & - & - & [1] & - & - \\
\hline fuscula Crotch & 4 & 1 & 1 & [4] & [4] & {$[4]$} \\
\hline harilana rubia Bechyne \& Bechyne & - & - & - & [7] & - & - \\
\hline hirtipennis (Melsheimer) & 7 & 1 & 2 & {$[4],[3],[9]$} & {$[5],[10]$} & {$[4],[5],[10],[9]$} \\
\hline humeralis Dury & - & - & - & [4] & - & [4] \\
\hline intermedia Foudras & 4 & 4 & & {$[3]$} & {$[5]$} & {$[5]$} \\
\hline krali Döberl & 1 & - & 1 & [3] & {$[5]$} & {$[5],[3]$} \\
\hline lobata Crotch & - & - & - & [4] & - & [4] \\
\hline muehlei Döberl & 1 & 1 & - & - & [5] & {$[5]$} \\
\hline papa sp. n. & 20 & 2 & 2 & {$[6]$} & {$[6]$} & {$[6]$} \\
\hline priesneri (Heikertinger) & 6 & 5 & 1 & [3] & {$[5],[3],[8]$} & {$[5]$} \\
\hline pubescens (Koch) & 119 & 17 & 2 & {$[4],[3]$} & {$[5],[8]$} & {$[4],[5]$} \\
\hline robusta Jacoby & - & - & - & {$[4]$} & - & [4] \\
\hline setosella (Fairmaire) & 5 & 2 & 3 & {$[11]$} & {$[5]$} & {$[5]$} \\
\hline similaris Gentner & 4 & 4 & - & - & {$[10]$} & {$[10]$} \\
\hline solani (Blatchley) & - & - & - & [4] & - & {$[4]$} \\
\hline subcrinita (LeConte) & 4 & 1 & 1 & [4] & {$[10]$} & {$[4],[10]$} \\
\hline tuberis Gentner & 23 & 9 & 4 & {$[4]$} & {$[10]$} & {$[4],[10],[6]$} \\
\hline ubaquensis Harold & - & - & - & [7] & - & - \\
\hline warchalowskii (Mohr) & - & - & - & - & {$[5]$} & {$[5]$} \\
\hline yanazara Bechyne & - & - & - & [7] & - & - \\
\hline
\end{tabular}

References: [1] - Barriga-Tunón, 2011; [2] - Bezděk \& Batelka, 2011; [3] - Borowiec, 2013; [4] - Deczynski, 2014; [5] - Döberl, 2000; [6] - EPPO, 2011; [7] - Gaiani, 2014; [8] - Heikertinger, 1950; [9] - Orlova-Bienkowskaja, 2014; [10] - Seeno \& Andrews, 1972; [11]- Smirnov, 2006.

de Investigação Agrária e Veterinária (Portugal), Russian Plant Quarantine Center, Zoological Institute of Russian Academy of Sciences, Moscow State Pedagogical University (Russia), and private collections of L.N. Medvedev and A.O. Bieńkowski (Russia) and M. Döberl (Germany) (Table 1).

\section{RESULTS}

Examination of 20 specimens of the pest from Portugal and comparison of them with the paratypes of E. similaris has revealed that the pest is not $E$. similaris. The specimens from Portugal do not correspond to the type specimens and the original description of E. similaris by Gentner (1944) and subsequent description by Seeno \& Andrews (1972) (Table 2, Figs 1,2). The pest damaging potato tubers in Portugal is undoubtedly not E. similaris as it differs significantly in the shape of its spermatheca, aedeagus and other characters.

The damage that larvae of the invasive pest do to potato tubers is similar to that of E. tuberis (Boavida et al., 2013). But comparison of the pest with the paratypes of E. tuberis from the National Museum of Natural History (USA) has revealed that the pest is not E. tuberis. We tried to identify the pest using an analysis of the characters of all the species of Epitrix native to the Holarctic (Döberl, 2010; Riley et al., 2003; Deczynski, 2014; EPPO, 2011) and all known Epitrix pests of potato in the world (Saunders et al., 1983; Vreugdenhil et al., 2011). But the pest clearly differs from all of them. So herewith it is described as a new species.

\section{Epitrix papa sp. $\mathbf{n}$.}

Type specimens of Epitrix papa sp. n.: Holotype (đ), paratypes $(13 \hat{\partial}, 6$ 우). The specimens were collected 24.iii.2015 from cages in the INIAV (Instituto Nacional de Investigação Agrária e Veterinária) in Lisbon. The culture was established in 2012 from adults collected from a farm near the village of Toxofal, located $70 \mathrm{~km}$ north of Lisbon and refreshed with wild adults from the same location twice a year. Holotype and three paratypes will be deposited in the collection of Zoological Institute of Russian Academy of Sciences (St.-Petersburg, Russia), four paratypes in the National Museum of Natural History (Washington, USA), four paratypes in the Natural History Museum (London, UK), 
TABLE 2. Comparison of characters of Epitrix similaris from California and Epitrix papa sp. n. from Portugal.

\begin{tabular}{|c|c|c|c|c|c|c|}
\hline \multirow[b]{2}{*}{$\begin{array}{l}\text { Sources of } \\
\text { information }\end{array}$} & \multicolumn{3}{|c|}{ Epitrix similaris } & \multicolumn{3}{|c|}{ Epitrix papa sp. n. } \\
\hline & $\begin{array}{c}\text { Three male paratypes } \\
\text { and one male identified } \\
\text { by T. Seeno }\end{array}$ & $\begin{array}{l}\text { Gentner, } \\
1944\end{array}$ & $\begin{array}{c}\text { Seeno \& Andrews, } \\
1972\end{array}$ & $\begin{array}{l}\text { Twenty specimens } \\
\text { from Portugal }\end{array}$ & $\begin{array}{c}\text { EPPO, } \\
2011\end{array}$ & $\begin{array}{c}\text { Boavida \& } \\
\text { Germain, } 2009\end{array}$ \\
\hline $\begin{array}{l}\text { Punctures on } \\
\text { pronotum }\end{array}$ & \multicolumn{3}{|c|}{ coarse and close } & \multicolumn{3}{|c|}{ more fine and sparse } \\
\hline $\begin{array}{l}\text { Distances between } \\
\text { punctures }\end{array}$ & less than their diameters & - & - & $\begin{array}{l}\text { more than their } \\
\text { diameters }\end{array}$ & - & - \\
\hline $\begin{array}{l}\text { Transverse antebasal } \\
\text { pronotal impression }\end{array}$ & deep & - & - & $\begin{array}{l}\text { weak to obsolete, } \\
\text { especially medially }\end{array}$ & - & - \\
\hline $\begin{array}{l}\text { Lateral margin of } \\
\text { pronotum }\end{array}$ & serrated & - & - & \multicolumn{3}{|c|}{ not serrated } \\
\hline Dorsal coloration & \multicolumn{2}{|c|}{ "piceous" (brownish-black) } & - & $\begin{array}{l}\text { black with bronze } \\
\text { reflection }\end{array}$ & - & - \\
\hline $\begin{array}{l}\text { Setae in elytral } \\
\text { intervals } 1-5\end{array}$ & $\begin{array}{c}\text { form } 2 \text { irregular rows, } \\
\text { so the beetle looks more } \\
\text { pubescent }\end{array}$ & - & - & $\begin{array}{c}\text { form } 1 \text { regular row, } \\
\text { so the beetle looks less } \\
\text { pubescent }\end{array}$ & - & - \\
\hline Apex of the aedeagus & pointed & - & pointed & blunt & - & - \\
\hline Spermathecal pump & - & - & $\begin{array}{l}\text { attached to the top } \\
\text { of receptacle and } \\
\text { lies in sagittal plane }\end{array}$ & $\begin{array}{r}\text { attached to the lateral s } \\
\text { not lie in }\end{array}$ & $\begin{array}{l}\text { de of rece } \\
\text { gittal ple }\end{array}$ & tacle and does \\
\hline
\end{tabular}

four paratypes in the private collection of M. Döberl (Abensberg, Germany) and four paratypes in the private collection of A.O. Bieńkowski (currently at the A.N. Severtsov Institute of Ecology and Evolution, Russian Academy of Sciences, Moscow).

Comparative type material. Epitrix similaris paratypes: California, Playa del Roy, 20.4.1935, A.T. McClay leg., $1 \delta^{\lambda}$; California, Santa Barbara, 16.6.1932, A.T. McClay leg., 1ठ; California, Monterey Co., Paraiso Springs, 5.5.1922, 10̄. Epitrix tuberis paratypes: Washington, Satus, 24.6.1940, H.P. Lomdester leg., 1ð’; Nebrasca, Scottsbluff, 28.6.1943, on potato, R.E. Hill leg., $1{ }^{\lambda} ;$ Nebrasca, Scottsbluff, 27.9.1940, on potato, H.-D. Tate leg., 13\%; Nebrasca, Scottsbluff, 28.6.1943, on potato, R.E. Hill leg., 1万亍; Colorado, Ft. Collins, 22.10.1931, 1 우.

\section{Description}

Male (holotype) (Figs 1, 2). Body elongate, length $1.72 \mathrm{~mm}$, width of elytra $0.85 \mathrm{~mm}$, pronotum 1.6 times as wide as long, ratio of width of elytra to width of pronotum 1.38. Body shiny, smooth, with head, pronotum, and elytra without microsculpture, not alutaceous; above black, with weak bronze reflection, femora dark brown (piceous) with apices yellow, tibiae, tarsi, and antennae yellow (11th antennomere slightly darkened). Combined width of eyes when viewed from front 1.3 times less than interocular distance. Frontal ridge narrow, convex. Supracallinal sulci curved at angle. Vertex with 3 large setiferous pores near each eye. Pronotum evenly convex; entirely covered with moderately large distinct punctures separated by approximately twice their diameter; pronotal lateral margin with setae, but not serrated; anterolateral callosity with obtuse angle, the callosity as long as $0.3-0.4 \times$ the rest part of lateral side, transverse antebasal impression weak, longitudinal basal furrows distinct. Elytra with humeral calli weak but distinct, with 11 regular rows of large dense punctures, sutural row abbreviated, ending at basal $1 / 3$ of elytral length, others distinct to apex, with single row of setifer- ous pores at intervals between puncture rows; setae white, long, slightly longer than intervals between puncture rows. Pygidium with distinct longitudinal furrow except near apex. Last abdominal sternite convex, unmodified. Tarsi narrow, with 1 st protarsomere slightly narrower than the apex of fore tibia. Aedeagus with almost parallel lateral sides, apically rounded, with small lamella, in lateral view evenly weakly curved over almost entire length, with apex weakly curved dorsally. Males (paratypes). Body length 1.7-1.8 mm. Females (paratypes). Body length 2.1-2.2 $\mathrm{mm}$. Transverse antebasal impression on pronotum weak to obsolete (especially medially). Last abdominal sternite convex, unmodified. Spermatheca: receptacle curved and slightly constricted medially, spermathecal pump attached to lateral side of the apex of receptacle and does not lie in the sagittal plane.

\section{Differential diagnosis}

Epitrix papa sp. n. differs from Palaearctic E. pubescens (Koch) and E. intermedia Foudras by the smooth, not alutaceous surface of pronotum, sparser punctures on pronotal disk, and from the other black or dark metallic Palaearctic species by a short sutural row of punctures on elytra ending at basal $1 / 3$ of elytral length. Epitrix papa sp. n. differs from most Epitrix species inhabiting North America north of Mexico by the bronze reflection of the dorsal body surface. In addition, it differs from E. cucumeris, E. tuberis and E. similaris by the even, not serrated lateral border of pronotum, weak to obsolete pronotal antebasal impression (especially medially), and one row of elytral setae in each interval between punctures; from E. fuscula Crotch by the even lateral border of pronotum, sparser punctures on pronotal disk (punctures usually separated by intervals $2 \times$ wider than their diameter), and aedeagus not angularly broadened at mid-length; from E. brevis Schwarz and $E$. 

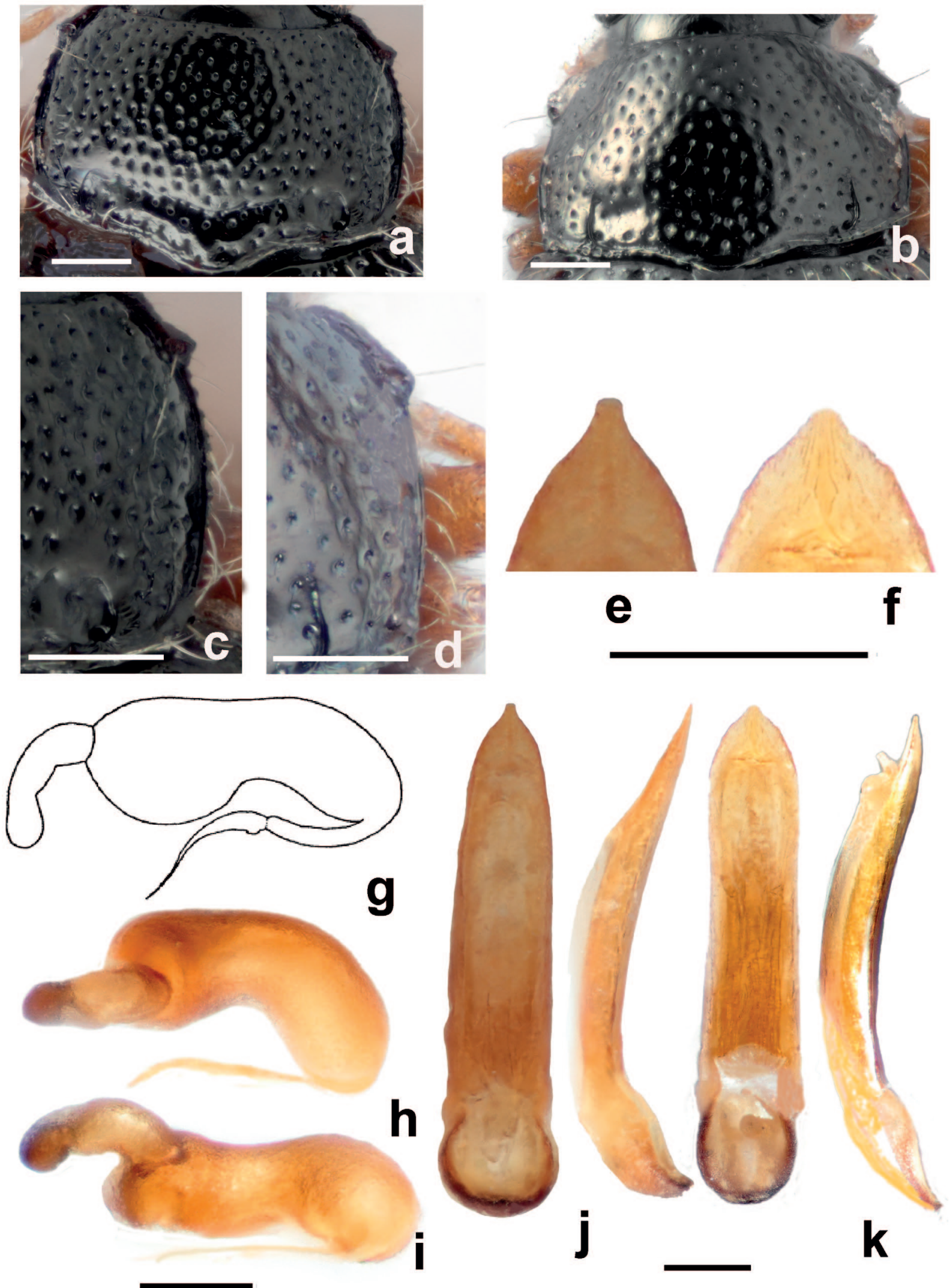

Fig. 1. Differences between Epitrix papa sp. n. from Portugal and E. similaris from California. a - pronotum of E. similaris paratype, $\mathrm{b}$ - pronotum of $E$. papa holotype, c - lateral margin of pronotum of $E$. similaris paratype, d - lateral margin of pronotum of $E$. papa holotype, $\mathrm{e}$ - apex of the aedeagus of $E$. similaris paratype, $\mathrm{f}$ - apex of the aedeagus of $E$. papa holotype, $\mathrm{g}-$ spermatheca of $E$. similaris, lateral view, h - spermatheca of $E$. papa paratype, lateral view, $\mathrm{i}$ - spermatheca of $E$. papa, ventral view, $\mathrm{j}$ - aedeagus of $E$. similaris paratype, ventral and lateral view, $\mathrm{k}$ - aedeagus of $E$. papa holotype, ventral and lateral view. Figures are original except $\mathrm{g}$ after Seeno \& Andrews, 1972. Scale bars $0.1 \mathrm{~mm}$. 


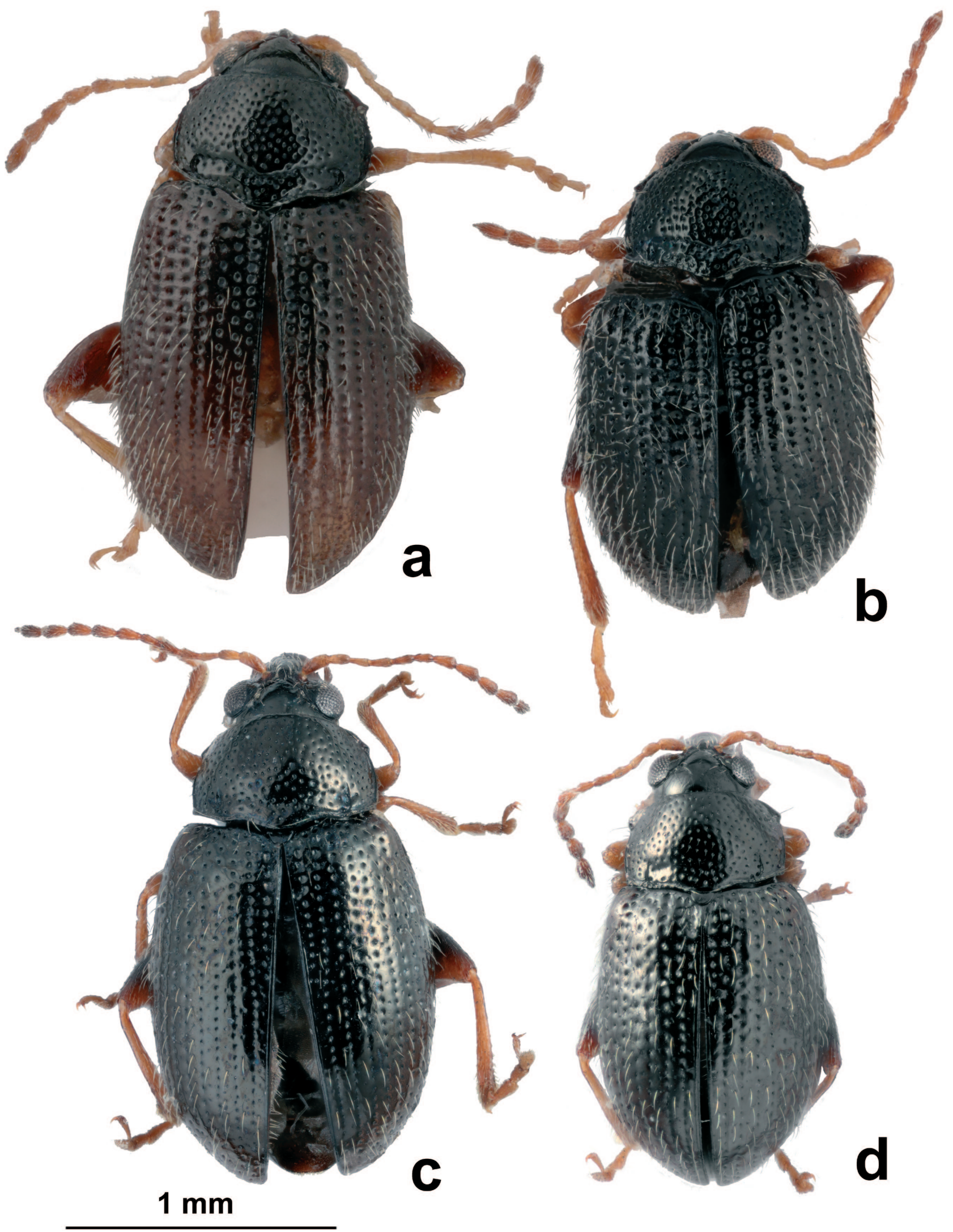

Fig. 2. Total view of Epitrix. a - E. tuberis paratype, female, $\mathrm{b}-$ E. similaris paratype, male, $\mathrm{c}-$ E. papa sp. n. paratype, female, $\mathrm{d}-$ E. papa, holotype, male.

lobata Crotch by elongate body; from E. robusta Jacoby by smaller body length, even lateral border of pronotum, and sparser punctures on pronotal disc. It differs from $E$. sub- crinita, the only other known species with bronze coloration in this region, by the even lateral border of pronotum, sparser punctures on pronotal disk, and differently shaped 
aedeagus: evenly arc-shaped and slightly curved dorsally at the apex. It differs from the potato pests from $\mathrm{C}$. and $\mathrm{S}$. America as follows: Epitrix papa sp. n. differs from E. fuscata (Duval) by the bronze reflection of dorsal surface, elytral setae much sparser, and pronotum covered with sparser punctures on disc and without serration at lateral margin. It differs from E. ubaquensis Harold in the body being more elongate, with lateral sides nearly parallel at mid-length, in dorsal coloration black with bronze reflection, anterior and middle femora dark with apex yellow, pronotal antebasal impression shallow, and elytral humeral calli weak. It differs from E. harilana rubia Bechyne \& Bechyne in pronotal lateral margin without serration and antebasal pronotal impression more shallow, especially medially. It differs from E. yanazara Bechyne in antebasal pronotal impression more shallow.

Etymology. The name "papa" means "potato" in Spanish.

Host plants. Solanum tuberosum, S. melongena, S. nigrum, Lycopersicon esculentum, Datura stramonium (Boavida et al., 2013).

Distribution. Portugal, Spain. The damage to potato tubers caused by this species was detected in 2004 in the northern part of Portugal (Oliveira et al., 2008). Then it was realized that this species is widely distributed in Portugal (Boavida \& Germain, 2009). In 2008 a single adult was found in Spain, at Xinzo, near the Portuguese border (Boavida \& Germain, 2009). In 2014 the pest was detected in A Coruña, Ourense and Pontevedra provinces in Spain (EPPO, 2014). Native range is unknown. It is quite possible that this pest is from North America. First, it was detected in Europe at the same time and in the same place with E. cucumeris native to North America. Second, it is believed that the origin of Epitrix in Portugal is related to the bulk imports of seed potatoes from Canada (Eyre \& Giltrap, 2012). Third, at least 30\% of North American Epitrix species are undescribed (Riley et al., 2002; Deczynski, 2014). Theoretically, introduction from outside the Holarctic is also possible.

\section{DISCUSSION}

It is rather surprising that E. papa sp. n. was not described before it arrived in Europe. But similar cases are known for beetles. For example, Paropsisterna selmani Reid \& De Little (Coleoptera: Chrysomelidae: Chrysomelinae), a significant pest of plantations of eucalypts native to Australia, was described only when it was detected in Ireland (Reid \& De Little, 2013). Quarantine measures to prevent insects entering a country tend to focus on well-known pests but a large proportion of the recently established nonnative pests were not known to cause significant damage in their native range, or were not even known to science before their introduction (Roques et al., 2014). A revision of the genus Epitrix world-wide or at least in North America is now needed to identify the native range of E. papa sp. n. Since the new potato flea beetle recently detected in Europe that damages potato tubers is not $E$. similaris, the name " $E$. similaris" should be removed from the A2 list of quaran- tine pests of EPPO and from lists of quarantine pests of European countries.

ACKNOWLEDGEMENTS. I would like to thank A.S. Konstantinov (National Museum of Natural History, USA), M. Döberl (Germany) and J.-F. Germain (Agence nationale de sécurité sanitaire de l'alimentation, de l'environnement et du travail, France) for valuable remarks, C. Boavida (Instituto Nacional de Investigação Agrária e Veterinária, Portugal), A.S. Konstantinov, S.A. Kurbatov (Russian Plant Quarantine Centre), M. Döberl (Germany), L.N. Medvedev and A.G. Moseyko (Russian Academy of Sciences) for loan of material for this study, A. Deczynski (University of Delaware, USA) and E.G. Riley (Texas A\&M University, USA) for valuable information and help in obtaining some important literature, K.V. Makarov (Moscow State Pedagogical University) for preparing the photographs, and A.O. Bieńkowski (A.N. Severtsov Institute of Ecology and Evolution, Russian Academy of Sciences) for the help in examination of material. This study was supported by Russian Foundation for Basic Research (project No. 15-29-02550).

\section{REFERENCES}

BARRIGA-TuÑón J.E. 2011: Coleoptera Neotropical [WWW document]. URL: http://coleoptera-neotropical.org/paginaprincipalhome.html [accessed 23 May 2015].

Beenen R. \& Roques A. 2010: Leaf and seed beetles (Coleoptera, Chrysomelidae). - BioRisk 4: 267-292.

Boavida C. 2009: Presence in Portugal of Epitrix similaris Gentner (Coleoptera: Chrysomelidae: Alticinae), an exotic pest of potato tubers. - Bol. Sanid. Veget. Plagas 35: 73-74.

Boavida C. \& Germain J.-F. 2009: Identification and pest status of two exotic flea beetle species newly introduced in Portugal: Epitrix similaris Gentner and Epitrix cucumeris (Harris). EPPO Bull. 39: 501-508.

Boavida C., Giltrap N., Cuthbertson A.G.S. \& Northing P. 2013: Epitrix similaris and Epitrix cucumeris in Portugal: damage patterns in potato and suitability of potential plants for reproduction. - EPPO Bull. 43: 323-333.

Borowiec L. 2013: The Leaf Beetles of Europe and the Mediterranean Subregion (Checklist and Iconography) [WWW document]. URL: http://www.biol.uni.wroc.pl/cassidae/European\%20Chrysomelidae/index.htm [accessed 26 April 2015].

CuthBertson A.G.S. 2015: Chemical and ecological control methods for Epitrix spp. - Global J. Environ. Sci. Manag. 1: 95-97.

Deczynski A. 2014: A Preliminary Revision of the Genus Epitrix Foudras (Coleoptera: Chrysomelidae: Galerucinae: Alticini) in America North of Mexico (University of Delaware) [WWW document]. URL: http://dspace.udel.edu/bitstream/handle/19716/13155/Deczynski\%2c\%20Anthony. pdf?sequence $=1$ [accessed 10 April 2015].

DöBerl M. 2000: Beitrag zur Kenntnis der Gattung Epitrix Foudras, 1860 in der Paläarktis. - Mitt. Internat. Entomol. Ver. 25: 1-23.

DöBerL M. 2010: Subfamily Alticinae. In Löbl I. \& Smetana A. (eds): Catalogue of Palaearctic Coleoptera. Vol. 6, Chrysomeloidea. Apollo Books, Stentrup, pp. 491-563.

Doguet S. 2009: Présence en Europe de deux espèces nord-américaines d'Epitrix (Coleoptera: Chrysomelidae: Alticinae). Entomologiste 65: 89-90.

EPPO 2011: Epitrix cucumeris, E. similaris and E. tuberis. EPPO Bull. 41: 369-373. 
EPPO 2014: Updated Situation of Epitrix similaris in Spain. EPPO Global Database [WWW document]. URL: https:// gd.eppo.int/reporting/article-2788 [accessed 10 April 2015].

EPPO 2015: EPPO Plant Quarantine Data Retrieval System. Version 5.3.5, 2015-02-10 [WWW document]. URL: http://www. eppo.int/DATABASES/pqr/pqr.htm [accessed 15 May 2015].

Eyre D. \& Giltrap N. 2012: Epitrix flea beetles: new threats to potato production in Europe. - Pest Manag. Sci. 69: 3-6.

GaIANI M. 2014: Chrysomelidae en MIZA [WWW document] URL: http://chrysomelidae.miza-ucv.org.ve/ [accessed 15 May 2015].

GENTNER L.G. 1944: The black flea beetles of the genus Epitrix commonly identified as cucumeris (Harris) (Coleoptera: Chrysomelidae). - Proc. Entomol. Soc. Wash. 46: 137-149.

Germain J.-F., Снatot C., Meusnier I., Artige E., Rasplus J.Y. \& CRUAUD A. 2013: Molecular identification of Epitrix potato flea beetles (Coleoptera: Chrysomelidae) in Europe and North America. - Bull. Entomol. Res. 103: 354-362.

Heikertinger F. 1950: Bestimmungstabelle der paläarktischen Arten der Crepidodera-Verwandtschaft weitesten Sinnes. Koleopt. Rundsch. 31: 117-121.

ICZN 1999: International Code of Zoological Nomenclature. 4th ed. International Trust for Zoological Nomenclature, London, $306 \mathrm{pp}$.

Oliveira R., Chatot C. \& Dedryver C.A. 2008: Détectée en Europe, une nouvelle altise. - Potato Planet 11: 30-34.

OrLova-BienKowsKaJA M.J. 2014: First record of the tobacco flea beetle Epitrix hirtipennis Melsheimer [Coleoptera: Chrysomelidae: Alticinae] in Russia. - EPPO Bull. 44: 44-46.

Reid C.A.M. \& De Little D.W. 2013: A new species of Paropsisterna Motschulsky, 1860, a significant pest of plantation eucalypts in Tasmania and Ireland (Coleoptera: Chrysomelidae: Chrysomelinae). - Zootaxa 3681: 395-404.
Riley E.G., Clark S.M., Flowers R.W. \& Gilbert A.J. 2002: Chrysomelidae Latreille, 1802. In Arnett R.H., Thomas M.C., Skelley P.E. \& Frank J.H. (eds): American Beetles. Vol. 2. Polyphaga: Scarabaeoidea through Curculionoidea. CRC Press, Boca Raton, FL, pp. 617-691.

Riley E.G., Clark S.M. \& Seeno T.N. 2003: Catalog of the Leaf Beetles of America North of Mexico (Coleoptera: Megalopodidae, Orsodacnidae and Chrysomelidae, Excluding Bruchinae). Coleopterists Society, Sacramento, 290 pp.

Roques A., Fan J.T., Courtial B., Zhang Y.Z., Yart A., AugerRozenberg M.A., Denux O., Kenis M., Baker R. \& Sun J.H. 2014: Planting sentinel European trees in eastern Asia as a novel method to identify potential insect pest invaders. - PloS ONE 10(5): e0120864, 19 pp.

Saunders J.L., King A.B. \& Vargas C.L. 1983: Plagas de cultivos en América Central. CATIE, Costa Rica, 92 pp.

Seeno T.N. \& Andrews F.G. 1972: Alticinae of California. Part I: Epitrix spp. (Coleoptera: Chrysomelidae). - Coleopt. Bull. 26: $53-61$

SMIRNov M.E. 2006: Epitrix setosella (Fairm., 1888) (Chrysomelidae) [WWW document]. URL: http://www.zin.ru/animalia/ coleoptera/rus/episetms.htm [accessed 15 May 2015].

Vreugdenhil D., Bradshaw J., Gebhardt C., Govers F., Taylor M.A., MacKerron D.K. \& Ross H.A. (eds) 2011: Potato Biology and Biotechnology: Advances and Perspectives. Elsevier, Amsterdam, 857 pp.

Webster R.P., LeSage L. \& DeMerchant I. 2012: New Coleoptera records from New Brunswick, Canada: Megalopodidae and Chrysomelidae. - ZooKeys 179: 321-348.

Received June 3, 2015; revised and accepted July 9, 2015 Prepublished online September 22, 2015 